\title{
Stroke and HIV: Correlation between Viral Load and Type of Stroke
}

\author{
Prince Eliot Galieni Sounga Bandzouzi ${ }^{1,2^{*}}$, Ghislain Armel Mpandzou ${ }^{1,3}$, \\ Josué Euberma Diatewa1,3, Patience Moudeko M'Foutou2, Dina Happia Motoula-Latou1,3, \\ Charles Godefroy Koubemba², Paul Macaire Ossou-Nguiet ${ }^{1,3}$, Donatien Moukassa ${ }^{1}$
}

${ }^{1}$ Faculty of Health Sciences, Marien N'GOUABI University, Brazzaville, Republic of Congo

${ }^{2}$ Department of Neurology, Loandjili General Hospital, Pointe-Noire, Republic of the Congo

${ }^{3}$ Department of Neurology, University Hospital of Brazzaville, Brazzaville, Republic of Congo

Email: *eliotprince2002@yahoo.fr

How to cite this paper: Sounga Bandzouzi, P.E.G., Mpandzou, G.A., Diatewa, J.E., Moudeko M'Foutou, P., Motoula-Latou, D.H., Koubemba, C.G., Ossou-Nguiet, P.M. and Moukassa, D. (2021) Stroke and HIV: Correlation between Viral Load and Type of Stroke. Neuroscience \& Medicine, 12, 163-167. https://doi.org/10.4236/nm.2021.124012

Received: October 30, 2021

Accepted: December 27, 2021

Published: December 30, 2021

Copyright $\odot 2021$ by author(s) and Scientific Research Publishing Inc. This work is licensed under the Creative Commons Attribution International License (CC BY 4.0).

http://creativecommons.org/licenses/by/4.0/ (c) (i) Open Access

\begin{abstract}
Introduction: The role of immunosuppression of $\mathrm{TCD} 4^{+}$lymphocytes in the onset of stroke in people living with HIV has been reported in numerous studies examining the co-morbidity of stroke and HIV. Objective: To determine the correlation between the viral load and the type of stroke. Methodology: This was a 7-month cross-sectional descriptive study carried out in the Neurology Department of Loandjili General Hospital in Pointe-Noire. The study population consisted of patients living with HIV who had a stroke confirmed by brain scan. The sero-immunological investigation consisted of looking for $\mathrm{T}$ lymphocyte typing from two kits: a $\mathrm{CD} 4^{+} \mathrm{T}$ lymphocyte typing reagent kit (BD FACS Presto TM) and a GeneXpert kit for viral load (Xpert ${ }^{\circledR}$ HIV-1 Viral Load). The database was made from the 2010 version of Microsoft Excel. Results: We included 16 patients living with HIV, $56 \%$ of whom were women with a sex ration of 0.78 . The mean age was $56.92 \pm 11.21$. The mean number of TCD4 ${ }^{+}$lymphocytes was $413.44 \pm 677.95 / \mathrm{mm}^{3}$; minimum: $93 / \mathrm{mm}^{3}$; maximum: $2854 / \mathrm{mm}^{3}$. The mean viral load was $17,996.31 \pm 20,982.22 / \mathrm{mm}^{3}$; minimum: $1002 / \mathrm{mm}^{3}$; maximum: $67,229 / \mathrm{mm}^{3}$. No significant difference between the viral load and the occurrence of the stroke $(p=0.13)$. Conclusion: Our study did not show a causal link between viral load, immunosuppression of $\mathrm{TCD} 4^{+}$lymphocytes and the onset of stroke.
\end{abstract}

\section{Keywords}

Viral Load, HIV, Stroke

\section{Introduction}

The Hummain Immunodeficiency Virus (HIV) is responsible for acquired im- 
munodeficiency syndrome (AIDS), characterized by the Dimunition of $\mathrm{CD}^{+} \mathrm{T}$ lymphocytes, resulting in the activation of $\mathrm{CD}^{+} \mathrm{T}$ lymphocytes. The lymphocyte immunomodulation mechanisms, marked by reactions to adjust and regulate the immune system because of pro-inflammatory and anti-inflammatory cytokines, allow the body to fight against the virus. These mechanisms are at the origin of several complications such as chronic inflammation, dyslipidemia and HIV neurotropism [1] [2]. They also promote the resurgence of certain central nervous system (CNS) infections with the consequence of the acceleration of atherosclerosis, vasculitis, that contribute to the occurrence of strokes [1] [2].

The role of immunosuppression of TCD4 $4^{+}$lymphocytes in the onset of stroke in people living with HIV has been reported in numerous studies examining the co-morbidity of stroke and HIV [3] [4] [5]. In Congo, in general, and in Pointe Noire, in particular, a recent study on HIV and stroke co-morbidity had established the correlation between the decrease in $\mathrm{CD} 4^{+} \mathrm{T}$ lymphocyte with risk factors for stroke and the increase in $\mathrm{CD}^{+} \mathrm{T}$ lymphocyte with ischemic stroke [2]. However, the cross-sectional nature of this study did not make it possible to establish a causal link between the decrease in $\mathrm{CD} 4^{+} \mathrm{T}$ lymphocyte, the increase in $\mathrm{CD} 8^{+}$lymphocyte and stroke.

It is in this context that we set out to determine the correlation between viral load and the type of stroke.

\section{Methodology}

It was a cross-cutting descriptive study conducted from January 1 to July 31 , 2019, a 7-month study period in the neurology department of Loandjili General Hospital of Pointe-Noire. Was selected, any HIV patient admitted to the neurology service victim of a stroke confirmed by a brain scanner was not selected, HIV patients who had a case of AIT, and those under statins.

Table 1 represents socio-demographic, clinical and sear-immunological characteristics.

A $4 \mathrm{ml}$ blood sample was taken from all patients at the bend of the elbow and packaged in a dry tube, then analyzed using a multiparametric biochemistry auto-analyzer (HUMA Star 100), from two kits: a $\mathrm{CD} 4^{+} \mathrm{T}$ cell typing reagent kit (BD FACS PrestoTM) and a GeneXpert viral load kit (Xpert ${ }^{\mathbb{B}} \mathrm{HIV}-1$ Viral Load).

The database was made from the 2010 version of Microsoft Excel. Qualitative variables were expressed as frequency and quantitative variables as mean \pm standard deviation. Fisher's Chi2 Exact test was used for univariate analysis between two variables.

Table 1. Sociodemographic, Clinical and Sero-Immunological Characteristics.

\begin{tabular}{cc}
\hline Sociodemographic & Age, sex \\
\hline Clinical Survey & Family HTA concept \\
& Diabetes \\
Sero-Immunological Survey & Obesity \\
\hline
\end{tabular}




\section{Results}

We included 16 patients living with HIV, 56\% of whom were women and $44 \%$ were men, or a sex ration of 0.78 . The mean age was $56.92 \pm 11.21$ with extremes ranging from 30 to 86 years.

Table 2 shows the distribution of the CD4 T lymphocyte count according to the type of stroke.

Table 3 describes the distribution of viral load according to the type of stroke.

Table 4 shows the distribution of HIV positive patients according to the number of CD4 T lymphocytes.

Table 5 shows the distribution of HIV positive patients according to viral load.

Table 2. Distribution of the CD4 T lymphocyte count according to the type of stroke.

\begin{tabular}{ccccccc}
\hline Number of CD4 & \multicolumn{2}{c}{ Ischemic stroke } & \multicolumn{2}{c}{ Hemorraghe stroke } & \multicolumn{2}{c}{ Total } \\
\hline & N & $\%$ & N & $\%$ & N & $\%$ \\
\hline$<200$ & 7 & 78 & 3 & 43 & 10 & 63 \\
$\geq 200$ & 2 & 22 & 4 & 57 & 6 & 37 \\
Total & 9 & 100 & 7 & 100 & 16 & 100 \\
\hline
\end{tabular}

$\mathrm{P}$ value $=0.30$

Table 3. Distribution of viral load according to the type of stroke.

\begin{tabular}{ccccccc}
\hline Number of CD4 $^{+}$ & \multicolumn{2}{c}{ Ischemic stroke } & \multicolumn{2}{c}{ Hemorraghe stroke } & \multicolumn{2}{c}{ Total } \\
\hline & N & $\%$ & N & $\%$ & N & $\%$ \\
\hline$<10,000$ & 2 & 22 & 5 & 71 & 7 & 44 \\
$>10,000$ & 7 & 78 & 2 & 29 & 9 & 56 \\
Total & 9 & 100 & 7 & 100 & 16 & 100 \\
\hline
\end{tabular}

$\mathrm{P}=0.13$.

Table 4. Distribution of HIV positive patients according to CD4 count.

\begin{tabular}{ccc}
\hline Nombre des CD4 & N & $\%$ \\
\hline$<200$ & 10 & 63 \\
$\geq 200$ & 6 & 37 \\
Total & 16 & 100
\end{tabular}

$\mathrm{P}$ value $=0.20$. The mean number of $\mathrm{TCD}^{+}$lymphocytes was $413.44 \pm 677.95 / \mathrm{mm}^{3}$; minimum: 93/ $\mathrm{mm}^{3}$; maximum: 2854/ $\mathrm{mm}^{3}$.

Table 5. Distribution of HIV positive patients according to viral load.

\begin{tabular}{ccc}
\hline Number of $\mathrm{CD4}^{+}$ & N & $\%$ \\
\hline$<10,000$ & 7 & 44 \\
$>10,000$ & 9 & 56 \\
Total & 16 & 100 \\
\hline
\end{tabular}

$\mathrm{P}$ value $=0.76$. The mean viral load was $17,996.31 \pm 20,982.22 / \mathrm{mm}^{3} ;$ minimum: $1002 / \mathrm{mm}^{3}$; maximum: $67,229 / \mathrm{mm}^{3}$. 


\section{Discussion}

Ischemic stroke was the most common mechanism of injury. The frequency of ischemic stroke was 56\% among cases. Our results are lower than those reported by Gnonlonfoun et al. [5] in Benin, Balogou et al. [6] in Togo, who noted a frequency of ischemic stroke of $67.3 \%$ and $77.5 \%$ respectively. However, some authors have reported a frequency of ischemic stroke greater than $90 \%$ [4] [7] [8]. The frequency of hemorraghe stroke in our study was $44 \%$ lower than reported in other studies in sub-Saharan Africa; this could be explained by the high frequency of hypertension [5] [9]. Hypertension is not only a risk factor for atherosclerosis but also the main cause of hemorraghe stroke. Durand et al. [10] reported a risk of hemorraghe stroke multiplied by 7.64 in people living with HIV at the AIDS stage (AIDS defined by the existence of an opportunistic infection of the system or by the $\mathrm{CD} 4^{+}$number lower than $200 / \mathrm{mm}^{3}$ ).

In our study, we did not find any significant difference between the type of stroke, the CD4 count and the viral load.

The multivariate study of known risk factors for stroke and HIV as an exposure factor for stroke in a case-control study model showed that HIV was not a risk factor independent of Stroke in stroke/HIV+ patients compared to stroke/ HIV- patients. The odds ratio of HIV (0.43; 95\% CI: 0.16 - 1.14) adjusted for other statistically significant risk factors (age sex, hypertension, obesity, triglycerides) made it possible to note that HIV is not a major factor in the onset of stroke [11]. However, several studies in the literature have shown that HIV infection increases the risk of stroke [5] [11] [12] [13]. However, the mechanisms of this stroke/HIV relationship remain multifactorial and have yet to be defined.

The in-depth study of the viral load in our patients; shows that there was no correlation between viral load and the occurrence of strokes. The CD4 T cell count was also not significant. The opposite results have been reported by Ortiz et al. [14], Mochan et al. [15], who reported that a CD4 count $<200$ increased the risk of stroke in HIV+. Chow et al. and Mapoure et al. [1] [12], reported a correlation between the decrease in TCD4 lymphocytes and the occurrence of stroke.

\section{Conclusion}

Our study did not show a causal relationship between viral load, immunosuppression of TCD4 $4^{+}$cells and the onset of stroke. Thus, we believe that immunosuppression of $\mathrm{CD} 4^{+} \mathrm{T}$ lymphocytes may be a risk marker rather than a risk factor for stroke.

\section{Conflicts of Interest}

The authors declare that they have no competing interests.

\section{References}

[1] Mapoure Njankouo, Y., Nepetsoun Nkongnin, I., Namme Luma, H., Mbatachou Ngahane, B.H., Barla, E., et al. (2016) Incidence des AVC chez les patients VIH+ sous TAR au long court. The Pan African Medical Journal, 24, Article No. 45. 
[2] Koumeka (2015) Risque d'accident vasculaire cérébral chez les personnes vivant avec le VIH, admis à l'Hôpital général de Loandjili: Etude des facteurs de risque. Thèse de Médecine, Université Marien Ngouabi de Brazzaville (FSSA), Congo.

[3] Sen, S., Rabinstein, A.A., Elkind, M.S.V. and Powers, W.J. (2012) Recent Developments Regarding Human Immunodeficiency Virus Infection and Stroke. Cerebrovascular Diseases, 33, 209-218. https://doi.org/10.1159/000335300

[4] Tipping, B., De Villiers, L., Wainwright, H., Candy, S. and Bryer, A. (2007) Stroke in Patients with Human Immunodeficiency virus Infection. Journal of Neurology, Neurosurgery and Psychiatry, 78, 1320-1324. https://doi.org/10.1136/jnnp.2007.116103

[5] Gnonlonfoun, D., Adjien-Kodjo, C., Adoukonou, T.A., Ossou-Nguiet, P.M., Mapoure, Y., Zannout, H., et al. (2013) L'infection à virus de l'immunodéficience humaine (VIH), facteur prédictif de gravité et de mortalité des accidents vasculaires cérébraux au Centre National Hospitalier et Universitaire HUBERT KOUTOUKOU MAGA (CNHU-HKM) de Cotonou, Bénin. African Journal of Neurological Sciences, 32, 14-23.

[6] Balogou, A.A.K., Grunitzky, E.K., Assogba, K., Apetse, K., Kombate, D. and Amouzouvi, D. (2008) Accidents vasculaires cérébraux chez le sujet jeune (15 à 45 ans) dans le service de neurologie du CHU Campus de Lomé. African Journal of Neurological Sciences, 27, 44-51.

[7] Artzen, M., Jubt, F., Evers, S., Volker, H., Fiori, W., Reichelt, D., et al. (2014) Cerebrovascular events in HIV-infected patients: an analysis of a cohort of $3203 \mathrm{HIV+}$ patients during the times of cART. International Journal of Neuroscience, 125, 601-611. https://doi.org/10.3109/00207454.2014.956870

[8] Morlat, P. (2013) Prise en charge médicale des personnes vivantes avec le VIH. Recommandations du groupe d'experts CNS et ANRS, France.

[9] Ossou-Nguiet, P.M., Gombet, T., Ossil-Ampion, M., Ellenga Mbolla, F.B., Otiabanda, G.F., Mahoungou-Nguimbi, K.C., et al. (2013) Facteurs de mortalité des accidents vasculaires cérébraux au CHU de Brazzaville. Revue Africaine d'Anesthésiologie et de Médecine d'Urgence, 18, 15-19. https://doi.org/10.1016/j.respe.2013.09.004

[10] Durand, M., Sheehy, O., Baril, J.G., Lelorier, J. and Tremblay, C.L. (2013) Risk of Spontaneaous Intracranial Hemorrhage in HIV-Infected Individuals: A PopulationBased Cohort Study. Journal of Stroke and Cerebrovascular Diseases, 22, e34-e41. https://doi.org/10.1016/j.jstrokecerebrovasdis.2012.03.014

[11] Heikinheimo, T., Chimbayo, D., Kumwenda, J.J., Kampondeni, S. and Allain, T.J. (2012) Stroke Outcomes in Malawi, a Country with High Prevalence of HIV: A Prospective Follow-Up Study. PLoS ONE, 7, e33765.

https://doi.org/10.1371/journal.pone.0033765

[12] Chow, F.C., Regan, S., Feske, S., Meigs, J.B., Grinspoon, S.K. and Triant, V.A. (2012) Comparison of Ischemic Stroke Incidence in HIV-Infected and Non-HIV-Infected Patients in a U.S. Health Care System. Journal of Acquired Immune Deficiency Syndromes, 60, 351-358.

[13] Dobbs, M.R. and Berger, J.R. (2009) Stroke in HIV infection and AIDS. Expert Review of Cardiovascular Therapy, 7, 1263-1271. https://doi.org/10.1586/erc.09.72

[14] Ortiz, G., Koch, S., Romano, J.G., Forteza, A.M. and Rabinstein, A.A. (2007) Mechanisms of Ischemic Stroke in HIV-Infected Patients. Neurology, 68, 1257-1261. https://doi.org/10.1212/01.wnl.0000259515.45579.1e

[15] Mochan, A., Modi, M. and Modi, G. (2003) Stroke in Black South African HIVPositive Patients: A Prospective Analysis. Strock, 34, 10-15. https://doi.org/10.1161/01.STR.0000043821.35051.FA 